\title{
Covid-19: Hungary's pandemic response may have been worse than the virus
}

\begin{abstract}
Hungary's maligned single party government responded to the covid-19 pandemic by simultaneously fearing the worst and assuming the best. For a crumbling healthcare system, the tactics may have been deadlier than the virus. Kata Karăth reports
\end{abstract}

\section{Kata Karáth freelance journalist}

The pandemic would be over before the summer. That's what the Hungarian government declared. As early as mid-April, Prime Minister Viktor Orbán said the infections would peak exactly on 3 May and ordered the gradual ease of lockdown measures starting on that day. By 16 June, the government had lifted virtually all coronavirus restrictions and officially ended a state of emergency.

It was an odd end to the fear and controversy that had surrounded the state of emergency laws. Critics had seen a step further towards autocracy that would be disastrous for a country whose public healthcare system was already crumbling under budget cuts, a brain drain of doctors, and the lack of a ministry of health since 2010 when Orbán came to power.

A confusing mix of light and heavy handed tactics saw the government seize control of hospitals and move cancer patients out of beds, but shy away from increases in testing and install lockdown restrictions that still allowed people to go to work, visit hairdressers, shop at markets, and attend funerals and weddings (see box).

On the one hand, the strategy seemed to work, at least during Hungary's first wave. As of 31 August, a country with about 10 million people had only 6139 confirmed cases and 615 coronavirus related deaths. On the other hand, it has left the country's healthcare sector in chaos.

\section{Austerity, but a new covid hospital}

Hungary has plunged in European health ratings since Orbán's appointment in 2010, although it was a trend set by previous administrations: health spending as a share of gross domestic product has dropped year on year since $2003,{ }^{1}$ reaching an all-time low of $4.41 \%$ in 2019. ${ }^{2}$ (In contrast, the UK spent $7.98 \%$ of gross domestic product that year, while Germany spent $9.9 \%$.)

Human Rights Watch say the lack of investment may have contributed to the spread of covid-19, with about $25 \%$ of total cases confirmed until mid-July contracted in hospitals. Hospital acquired covid-19 infections led to almost $50 \%$ of reported deaths at the time. ${ }^{3}$

This was despite the government taking hands-on control by appointing over 100 "hospital commanders," with no required medical or hospital management experience, to monitor medical resources and control their use during the pandemic.

"There is virtually a military dictatorship in Hungary," Ferenc Falus, Hungary's former medical chief, told The BMJ. "II's very fitting that even the hospital directors [previously appointed by the government] were not trusted, and thus soldiers and police officers were assigned to them.” The commanders look set to remain in place indefinitely, even after the state of emergency ended in June.

On 20 March, Orbán had ordered the construction of a slick, temporary hospital at the premises of Kiskunhalas prison. Under the slogan "Europe's most modern mobile epidemic hospital" it was finished in just two and a half weeks, providing 150 beds "to manage the sudden emergence of great pressure and a significant patient load," said Zoltan Kovacs, Hungarian secretary of state.

According to the government's website, the $3100 \mathrm{~m}^{2}$ hospital accommodates 36 wards and is equipped with a therapeutic observation unit; three way airlock gowning rooms; a reception and examination unit; a separate laboratory; $\mathrm{x}$ ray, ultrasound, and computed tomography machines; and ventilators.

Critics have decried the fact that such a state-of-the-art facility could be put together with immediate funds when public hospitals have been under austerity for decades. During the initial wave of the pandemic, the Kiskunhalas unit housed about 30 patients in total, but strangely the facility officially opened only on 1 October, when authorities transferred 43 patients from a local hospital owing to the rapid increase in newly confirmed cases.

\section{Hard measures}

One move that caused major upset was a government order for all hospitals to free up $60 \%$ of their beds by discharging non-covid-19 patients. Citing fears of a scenario like the one in Italy, the government aimed to free up about 36 ooo beds, though the exact number of patients affected remains unclear. Hospital directors had little choice over the matter, and the moves sparked a backlash from both the general public and the medical community.

Falus says the measure was another blow for the country's long collapsing healthcare system and in his opinion "will claim more victims in Hungary than the pandemic." Hungary has the highest cancer mortality rates in the European Union, and the country's ranking on amenable mortality is the fifth highest in the bloc. ${ }^{4}$

Local media reported several cases of patients with cancer or other terminal illnesses who were sent home to be cared for by family members. In an open 
letter, the Hungarian Medical Chamber, the country's professional medical association, called on the government to provide an explanation, backed by epidemiological data, for such a drastic decision. The government answered that it was preparing for a "worst case scenario."

That worst case scenario did not transpire, but a large number of non-emergency operations were cancelled between March and June. Although the exact number hasn't been made public because hospitals were forbidden by the government to disclose any information to the press, the head of the National Institute of Neuroscience said that instead of an average of 110 operations a week, they did only about 30 each week during the state of emergency. While many of these elective operations were rescheduled after the state of emergency was lifted, the healthcare system has not caught up with pre-pandemic numbers. According to the National Health Insurance Fund Management, the average waiting time for heart valve implantation jumped from 144 days in February to 174 days in October, but in the Northern Great Plain region the number rose to 206 days.

Miklós Kásler, an oncologist and the minister of the super ministry where healthcare currently sits, put the blame for patients whose condition worsened or who died after being sent home entirely on doctors for the way they interpreted his bed clearing order, an accusation that has been strongly rejected by the Hungarian Medical Chamber. "It is in the interest of the nation to have a trustworthy, corruption-free and patient-centred healthcare system that is transparent about its mistakes and continuously learns from them," said the body in a statement after the minister's accusations.

\section{Doctors' plight}

Hungary's healthcare professionals have had considerably less work in most hospitals after the majority of their patients were forcefully discharged. This has left many staff struggling to make ends meet.

The average general practitioner in Hungary earns less than twice as much as the average Hungarian, ${ }^{5}$ one of the lowest ratios in Europe. This has led to a massive emigration of health professionals, with an estimated 5500 doctors leaving Hungary to work elsewhere between 2010 and 2016.

In April, the government barred health workers from leaving the country without special ministerial permission until the end of the state of emergency. But according to the Union of Hungarian Doctors, more than 8000 healthcare workers left Hungary's healthcare system in the first half of 2020. While the Orbán government purchased around 16 ooo ventilators between March and May, official registries estimate that there are only about 2000 doctors and 2000 intensive care nurses in the country able to operate them.

Those that remained missed the extra income they might normally earn through overtime or other jobs, says Falus. The government allocated a one time bonus of HUF 500 ooo (around €1200; €1400; $\$ 1600$ ) for frontline health workers during the pandemic, and some, like those working in institutionalised elderly care, were excluded.

\section{Fear and complacency}

Hungary remains on edge. In September, the country quickly moved from logging several hundreds to over a thousand cases every day, as a covid-19 resurgence grips Europe. Orbán ordered the closing of borders to foreigners from 1 September and a nationwide ban on hospital and care home visits, but schools remain open and Orbán has repeatedly dismissed calls for a second lockdown, citing economic concerns.

Béla Merkely, a cardiologist and rector of Hungary's leading medical university, Semmelweis, believes the measures were lifted at the right time, a decision backed by scientific data, including his own study. He says the problem was that other countries already had a high level of infections at the time, with some citizens holidaying in Croatia and younger people partied too much, too soon. "In fact, we can say that our second wave [of coronavirus] is actually our first wave," he says, adding that the average age of newly confirmed patients is 33 , which shows that this time it mostly spreads through community transmission as opposed to imported cases from abroad.

Falus says Hungary survived its first wave because the outbreak in northern Italy had made the public "terribly frightened. By the time the stay-at-home order and curfew measures became official, a great many people were already at home and those who came home from abroad voluntarily or officially were placed in quarantine.”

Merkely thinks people became complacent after initial fears about the virus did not come to pass. Hungarians followed restrictions so well during the first wave that it kept numbers low, casting doubt in the population about the seriousness of the pandemic.

As of 14 October, Hungary had passed the 1000 death milestone, with around $43 \%$ of coronavirus victims dying since 1 September and approaching 42000 confirmed cases. Scientists have warned that testing capacityhas reached a maximum, ${ }^{6}$ with a threshold of about 10 ooo people a day (see box). There are genuine fears that the worst case scenario will actually come to pass, and Hungary's healthcare workforce are already weary.

\section{Testing failure}

Testing has been badly handled by many governments around the world and Hungary is no exception. Falus says about 15000 tests a day were needed to stay on top of the pandemic, but on most days numbers fluctuated between 1000 and 3700 .

There were real worries over the supply of test kits, which the government did not deal with. Hungary couldn't get hold of polymerase chain reaction (PCR) testing kits at the beginning of the pandemic, says Béla Merkely. "Solidarity within the European Union somewhat failed as nobody gave PCR kits to anyone. There were times when Semmelweis University only had enough PCR kits for 2-3 days. Only the import [of PCR testing kits] from China saved us."

"We purchased our own stock of PCR testing kits, from which we offered screening opportunities for care homes and homeless shelters we're operating," says Gábor Havasi, healthcare adviser at the Municipality of Budapest. Independently of the government, Havasi says Budapest's mayor also allocated the city's own funds for institutions to stock up on personal protective equipment and set up isolation rooms ahead of a potential second wave of infections.

On the other hand, the proportion of positive covid-19 tests was so low that health officials didn't see the need to do more tests, says Merkely, adding that they tested practically "everyone who coughed." Hungary's official policy is to test only those with symptoms who are essential workers, traced contacts of covid-19 positive patients, and those returning from abroad.

Merkely said the country's four medical universities received about five coronavirus patients in total a day. Since there were usually fewer than 100 new cases a day, health authorities and hospitals were also able to do thorough contact tracing.

As part of a coronavirus survey conducted by the medical universities and led by Merkely, nearly 10500 individuals were PCR tested nationwide in May, and the results suggested that, at the time, nearly 2500 people had active infection, while about 56500 had already had the disease. ${ }^{7}$ With cases rising in September, the government has stepped up to an average of 10000 to 12000 tests a day. It has also introduced a price 
cap on tests, which reached $€_{100}$ in private clinics around the country, reported Reuters, as the free tests provided by the healthcare sector have become slower and more difficult to come by. ${ }^{8}$

Correction: This story has been amended to clarify Béla Merkely's comments on restrictions and rising infection numbers.

Competing interests: I have read and understood the BMJ policy on declaration of interests and have no relevant interests to declare.

Commissioning and peer review: Commissioned, not externally peer reviewed.

1 Organisation for Economic Co-operation and Development. Health spending. Government/compulsory, \% of GDP, 1970-2019. https://data.oecd.org/chart/67QF

2 Organisation for Economic Co-operation and Development. Health spending. Government/compulsory, \% of GDP, 2005-2019. https://data.oecd.org/chart/655U

3 Human Rights Watch. Hungary: health care failures endanger lives. Aug 2020. https://www.hrw.org/hews/2020/08/04/hungary-health-care-failures-endanger-lives

4 Organisation for Economic Co-operation and Development, European Observatory on Health Systems and Policies. State of health in the EU: Hungary country health profile 2017. https://ec.europa.eu/health/sites/health/files/state/docs/chp_hu_english.pdf

5 Organisation for Economic Co-operation and Development. Health at a glance 2017.

6 Dunai M. Hungary passes COVID-19 milestones as testing hits limits. Reuters 2020 Oct 14 https://www.reuters.com/article/uk-health-coronavirus-hungary/hungary-passes-covid-19-milestones-as-testing-hits-limits-idUKKBN26Z1S5

7 Merkely B, Szabó AJ, Kosztin A, etalHUNgarian COronaVirus-19 Epidemiological Research (H-UNCOVER) investigators. Novel coronavirus epidemic in the Hungarian population, a cross-sectional nationwide survey to support the exit policy in Hungary. Geroscience 2020;42:1063-74. doi: 10.1007/s11357-020-00226-9. pmid: 32677025

8 Hungary daily coronavirus cases near 1,000, schools to stay open. Reuters 2020 Sept 12 https://www.reuters.com/article/us-health-coronavirus-hungary-record-idUSKBN2630GQ

This article is made freely available for use in accordance with BMJ's website terms and conditions for the duration of the covid-19 pandemic or until otherwise determined by BMJ. You may use, download and print the article for any lawful, non-commercial purpose (including text and data mining) provided that all copyright notices and trade marks are retained. 